\section{gRNA cassette}

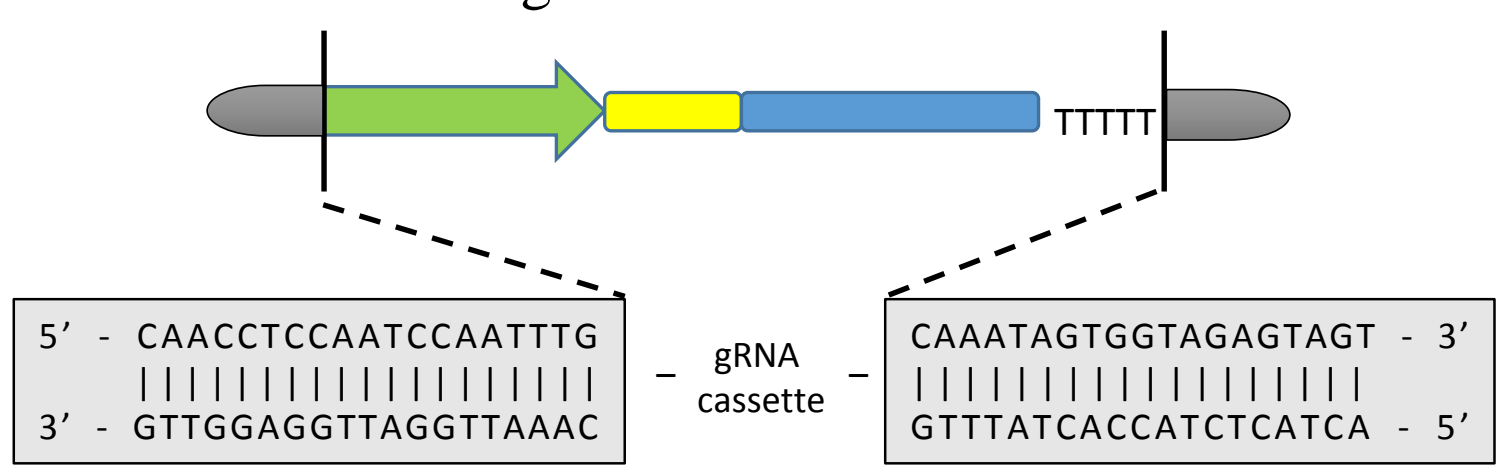

Treated by T4 DNA

polymerase $+\mathrm{dCTP}$

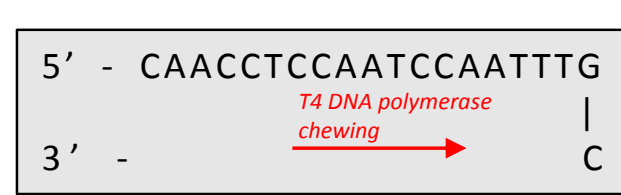

|| || || || || || || || | |

GTTTATCACCATCTCATCA - 5'

$\sqrt{2}$

gRNA
cassette

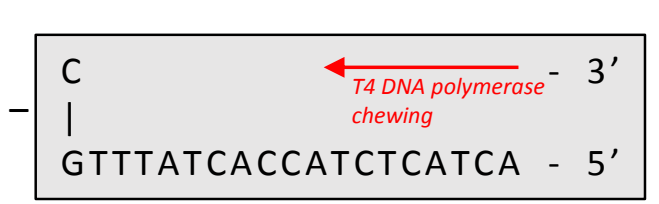

ANEp8-Cas9-LIC

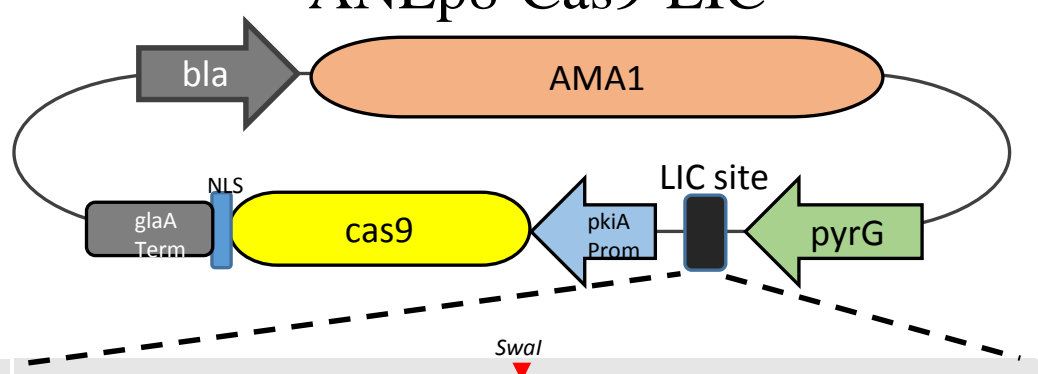

5' - Ġ'AACCTCCAATCCAATTTAAATAGTGGTAGAGTAGTC - 3' ||||||||||||||||||||||||||||||||||||||

3' - CGTTgGAgGTTAgGTIAAATTATCACCATCTCATCAG - 5'

Treated by T4 DNA polymerase + dGTP $\downarrow$

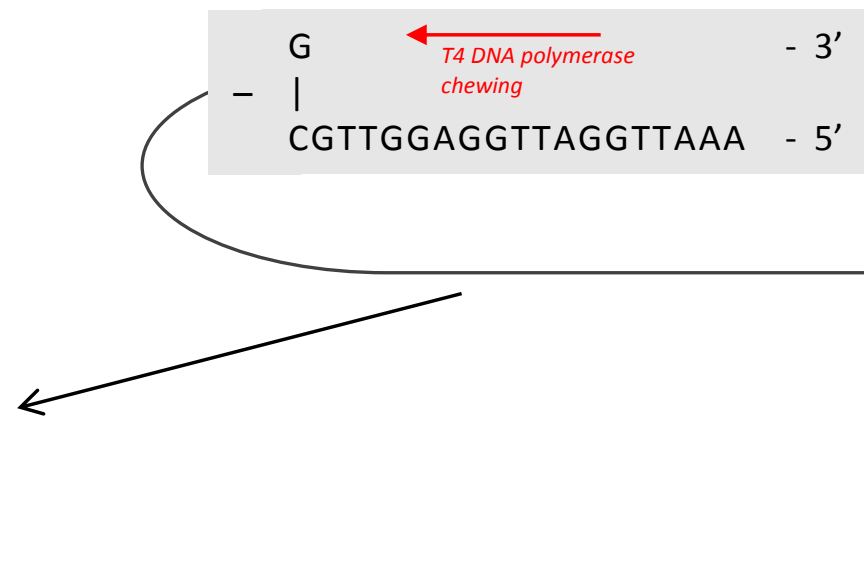

5' - AAATAGTGgTAGAGTAGTC

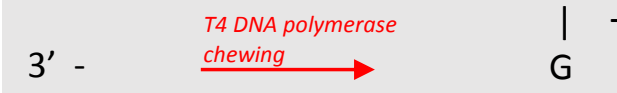

ANEp8-Cas9-gRNA

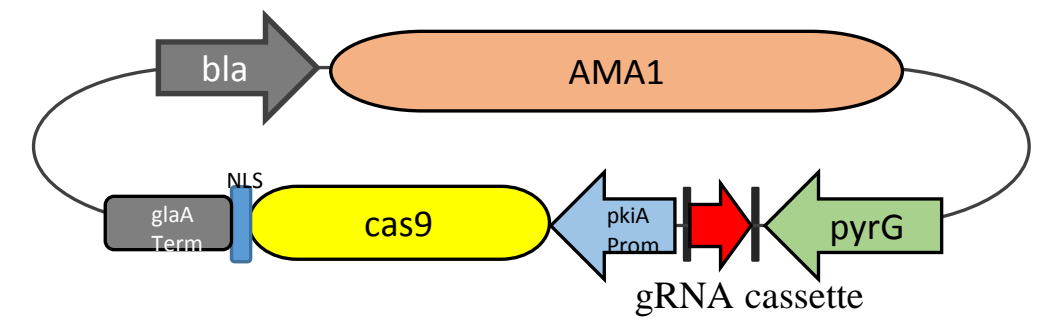

